\title{
Gold and metal enrichment in natural granitic melts during fractional crystallization
}

\author{
Roger Mustard* Predictive Mineral Discovery Cooperative Research Centre, Economic Geology Research Unit, School of \\ Earth Sciences, James Cook University, Townsville, QLD 4811, Australia \\ Thomas Ulrich* Earth and Marine Science Department, Australian National University, Canberra, ACT 0200, Australia \\ Vadim S. Kamenetsky School of Earth Sciences and Centre for Ore Deposit Research, University of Tasmania, GPO Box \\ 252-79, Hobart, TAS 7001, Australia \\ Terrence Mernagh Geoscience Australia, GPO Box 378, Canberra, ACT 0200, Australia
}

\begin{abstract}
Metal evolution in a composite granitic pluton was tracked by analyzing melt inclusions in 11 quartz samples from 7 zones at the Timbarra gold deposit, Australia. We present the first quantitative microanalyses of gold ( $\mathrm{Au}$ ) in granitic silicate melt inclusions using laser ablation inductively coupled plasma mass-spectrometry and show how Au and other metals become enriched during fractional crystallization in a granite intrusion. Au was enriched during fractionation from a monzogranite to a highly fractionated alkali-feldspar granite. Similar enrichment behavior for other metals implies that no gold-enriched precursor melt is required and fractional crystallization can enrich the Au concentration to economic levels. The low content of accessory oxides and sulfides, the absence of early Clbearing fluids, the volatile content in the melt, and a prolonged crystallization constitute important factors for extensive metal enrichment during crystal fractionation. These characteristics play a crucial role in felsic, highly fractionated plutons and their associated deposits such as intrusion-related Au deposits. The gold enrichment during fractionation also implies that $\mathrm{Au}$ is directly sourced from the granites.
\end{abstract}

Keywords: gold, metal enrichment, LA-ICP-MS, melt inclusions, fractional crystallization, intrusion-related Au deposit.

\section{INTRODUCTION}

The best-known intrusion-related metal deposits are porphyry $\mathrm{Cu}-\mathrm{Au}-(\mathrm{Mo})$ and granitic $\mathrm{Sn}-\mathrm{W}$ types, in which a direct connection between intrusions, magmatic Cl-bearing aqueous fluids, and the metal budget of the deposits has been recognized (Audétat et al., 1998; Candela, 1992; Halter et al., 2002; Hedenquist et al., 1994; Jugo et al., 1999; Ulrich et al., 1999). The recently defined intrusion-related gold deposit class is in marked contrast with low-salinity, carbon dioxide-rich aqueous fluids forming the dominant fluid type (Lang and Bager, 2001; Lang and Titley, 1998; Thompson et al., 1999). The location of these gold deposits within lithophile (Sn-W) provinces, the common association of gold with $\mathrm{Bi}$, and the low concentrations of $\mathrm{Cu}, \mathrm{Pb}$, and $\mathrm{Zn}$ (commonly $<100 \mathrm{ppm}$ ) also distinguish them from typical porphyry deposits (Thompson et al., 1999). The intrusions are commonly texturally and chemically zoned, and occur at deeper crustal levels than porphyry systems. The gold mineralization occurs in, or adjacent to, the more felsic portions of such composite intrusions, suggesting that fractionation plays a role in the genesis of intrusion-related gold

\footnotetext{
*Current addresses: Mustard-Auzex Resources Limited, 38 Seaward Crescent, Townsville, QLD 4810, Australia; e-mail: rmustad@bigpond.net.au. Ulrich-Research School of Earth Sciences, Australian National University, Canberra, ACT 0200,
} Australia. deposits (i.e., Fort Knox and Timbarra; Bakke, 1995; Mustard, 2001, 2004; Thompson et al., 1999; Fig. 1). However, this has never been proven.

\section{GEOLOGY OF THE TIMBARRA PLUTON AND SAMPLE DESCRIPTION}

The Au deposit at Timbarra in the New England Fold Belt, East Australia, is an example of an intrusion-related gold deposit with disseminated gold mineralization and minor late-stage vein mineralization in the roof zone of a composite pluton (Mustard, 2001, 2004). The Timbarra pluton consists of two major intrusions (Bungulla monzogranite and Stanthorpe syenogranite) that have several texturally and chemically different zones (for details see Mustard, 2001, 2004; see Data Repository ${ }^{1}$ ). Seven individual zones of the pluton can be readily distinguished based on texture, grain size, mineralogy, and field relationships. Zones $1-3$ and $4 \mathrm{~A}-4 \mathrm{C}$ are found in the outer Bungulla monzogranite and zones 5-7 are in the inner Stanthorpe syenogranite (Fig. 1). Zone 3 is the least fraction-

${ }^{1}$ GSA Data Repository item 2006022, supplementary information, Figure DR1, Tables DR1 and DR2, and element concentrations of individual melt inclusions from the gold-bearing zone, is available online at www.geosociety.org/pubs/ft2006.htm, or on request from editing@geosociety.org or Documents Secretary, GSA, P.O. Box 9140, Boulder, CO 80301, USA. ated coarse-grained hornblende-biotite monzogranite and zones 6 and 7 are the most fractionated rocks with textures (e.g., miarolitic cavities and unidirectional solidification textures) that are indicative of formation near the magmatic-hydrothermal transition where fluids coexisted with late-stage melts (e.g., Candela, 1997; Mustard, 2004). Based on petrographic contact relationships and geochemical analyses it is envisaged that zones $1-3$, $4 \mathrm{~A}-4 \mathrm{C}, 6 \mathrm{~A}-6 \mathrm{~B}, 5 \mathrm{~A}-5 \mathrm{~B}$, and 7 represent individual pulses of magma (Mustard, 2004). The whole-rock geochemistry and trace element modeling, however, highlight a cogenetic fractionation series that displays higher $\mathrm{Rb} /$ $\mathrm{Sr}$ values with increasing $\mathrm{SiO}_{2}$ (Fig. 2; Table DR1 [see footnote 1]), and thus indicates a common stratified source region (Mustard, 2004). The magma pulses are tapped from different zones of the stratified magma chamber

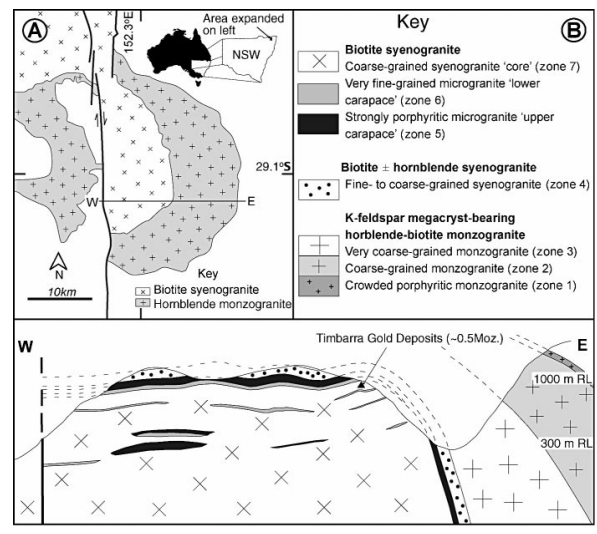

Figure 1. Geology of Timbarra pluton. A: Location of Timbarra pluton, northern New South Wales, Australia, and east-west cross section. B: Simplified east-west geologic cross section through Timbarra pluton displaying spatial relationships between zones 1-7. Pluton comprises outer K-feldspar megacryst-bearing hornblende-biotite monzogranite (zones 1-3), intermediate zone of biotite \pm hornblende syenogranite (zone 4 ), and core of biotite syenogranite (zones 57). Timbarra gold deposit $\left(\sim 0.5 \times 10^{6}\right.$ oz of gold) is hosted within upper $250 \mathrm{~m}$ of coarse-grained syenogranite core (zone 7) and partly by overlying fine-grained microgranite lower carapace (zone 6). Gold mineralization forms flat-lying sheet, conformably constrained beneath porphyritic microgranite upper carapace (zone 5). 


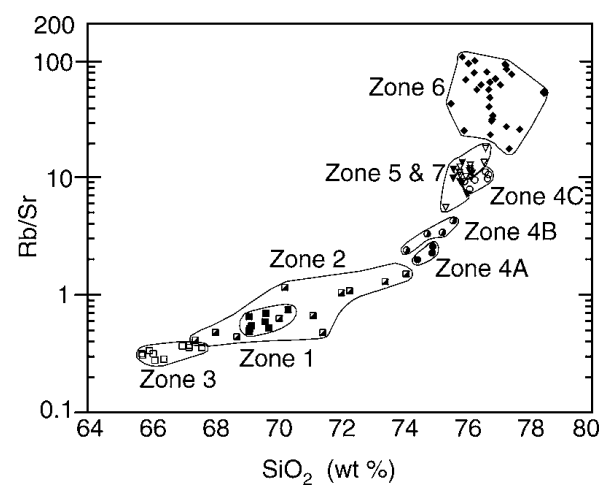

Figure 2. $\mathrm{Rb} / \mathrm{Sr}$ vs. $\mathrm{SiO}_{2}$ plot from wholerock data of different zones in Timbarra pluton. Data display coherent fractionation trend of increasing $\mathrm{Rb} / \mathrm{Sr}$ with increasing $\mathrm{SiO}_{2}$.

and intruded each other. Upon emplacement the melts underwent in situ crystal fractionation. The early granitic zones are characterized by low contents $(<1 \%)$ of magnetite, titanite, and ilmenite, whereas the later zones contain trace magnetite and ilmenite.

Primary magmatic quartz for silicate melt inclusion analysis was selected from each of the seven distinctive zones. The melt inclusions range from $5 \mu \mathrm{m}$ to $\sim 150 \mu \mathrm{m}$ and contain numerous solid phases (Fig. 3) that were distinguished by Raman spectroscopy. The quartz phenocrysts show no signs of resorption or recrystallization or different generations of melt inclusions. Based on this and the chemical evolution of the $\mathrm{Rb} / \mathrm{Sr}$ in the melt inclusions, we are confident that the trapped melt is representative of the zones in which the inclusions are found. All inclusions were analyzed in quartz, which commonly is a late phase to crystallize, and thus minimizes the chance of trapping melt from a much earlier stage in the system.

\section{ANALYTICAL METHODS}

Individual melt inclusions were analyzed by laser ablation inductively coupled plasmamass spectrometry (LA-ICP-MS) in quartz crystals that showed very low trace element content. To quantify the data we used $\mathrm{K}$ as an internal standard from whole-rock analyses and microprobe analyses of homogenized and exposed melt inclusions. A detailed description of the data processing is given in the Data Repository (see footnote 1).

\section{GOLD CONTENT OF SILICIC MELT INCLUSIONS}

Average melt inclusion concentrations of the individual zones are shown in Table 1 and single inclusion analyses from the most fractionated zone 6B are given in Table DR2 (see footnote 1). The nonhomogenized melt inclusions contained several daughter phases and a shrinkage bubble. They showed complex LAICP-MS spectra (Fig. 3) from which quanti-

Figure 3. Representative silicatemelt inclusions in quartz and timeresolved laser ablation inductively coupled plasmamass spectrometry (LA-ICP-MS) spectra of unexposed inclusion. $A$ : Silicate-melt inclusions define primary growth zone within 4-mmdiameter magmatic quartz grain zone 6. B: Large primary silicate-melt inclusion containing 1$2 \mu \mathrm{m}$ molybdenite daughter crystal (identified using laser Raman spectroscopy). Most common phase assemblages within melt inclusions comprise crystals of mica, albite ( $>50$ vol\%), quartz, rutile, pyrophyllite, calcite, vapor bubbles, and intersti-

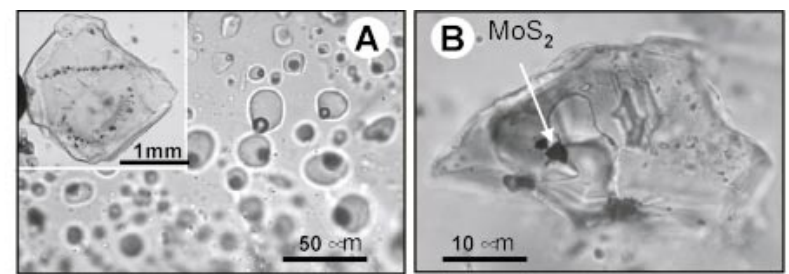

tial liquid. Less common phases include biotite, phenacite $\left(\mathrm{Be}_{2} \mathrm{SiO}_{4}\right)$, apatite, tourmaline, zircon, senarmontite $\left(\mathrm{Sb}_{2} \mathrm{O}_{3}\right)$, scheelite $\left(\mathrm{CaWO}_{4}\right)$, wulfenite $\left(\mathrm{PbMoO}_{4}\right)$, hematite, sassolite/ boric acid $\left(\mathrm{H}_{3} \mathrm{BO}_{3}\right)$, molybdenite, sphalerite, and stibnite. Unidentified opaque with spectrum peak at $\mathbf{2 5 0}$ is thought to be PbBiTe mineral based on Raman analysis. The majority of vapor bubbles have relatively constant bubble/inclusion volume ratio of $5 \mathrm{vol} \%$, contain no detectable gases, and are interpreted to represent shrinkage bubbles. Occasionally, larger bubble/inclusion volume ratios of 20-30 vol\% are observed with $\mathrm{CO}_{2},>\mathrm{N}_{2},>\mathrm{CH}_{4}$. C: LA-ICPMS spectra for gold-bearing silicate melt inclusion from zone 6 . Note that gold peak has strong spatial association with $\mathrm{Bi}, \mathrm{Sb}, \mathrm{Sn}, \mathrm{W}$, and Mo.

tative information on the daughter phases and element affinities could be obtained by observation of consistently overlapping peaks in the spectra. For example, a strong Au affinity for (Ca)-Fe-Ti phases and an unidentified $\mathrm{Pb}-\mathrm{Bi}$ Te phase has been deduced from overlapping peaks in several LA-ICP-MS spectra. This is consistent with the observation that free gold occurs in spatial association with $\mathrm{Pb}-\mathrm{Bi}$ and Ag-Bi tellurides in the ore zones (Mustard, 2001).

Gold was detected in melt inclusions analyzed from the most fractionated phase of the pluton (zone 6B) averaging 0. $12 \mathrm{ppm} \mathrm{Au}$ (range 0.02-0.96 ppm, Table DR2; see footnote 1). These $\mathrm{Au}$ values are in agreement with the range of experimentally determined gold solubilities in rhyolitic melts in the presence of Fe-oxides (Simon et al., 2003). One melt inclusion from zone $4 \mathrm{C}$ and three from zone $6 \mathrm{~B}$ returned very high $\mathrm{Au}$ concentrations (range 1. 2-17.2 ppm, Table DR2; see footnote 1) and were excluded from the average. These inclusions contained large visible opaque phases ( $\mathrm{Pb}-\mathrm{Bi}-\mathrm{Te}$ and $\mathrm{Ca}-\mathrm{Ti}$ phases as inferred from the LA-ICP-MS spectrum). The high values are most likely related to a "nugget effect," in which Au is both attached to and concentrated in those phases rather than dissolved in the silicate melt. Very small opaque phases were also found in some melt inclusions from the most fractionated zones 6 and 7 , indicating that oxides were present throughout the fractionation.

\section{METAL ENRICHMENT DURING FRACTIONATION}

The results of the melt inclusion analyses from each increasingly fractionated zone are shown in Figure 4. To assess the metal behavior during fractionation we compared the Sn, $\mathrm{Mo}, \mathrm{W}, \mathrm{Bi}, \mathrm{As}, \mathrm{Sb}, \mathrm{Cu}, \mathrm{Pb}, \mathrm{Zn}$, and $\mathrm{Au}$ concentrations in the whole rock (Table DR1; see footnote 1) and in the melt inclusions for each zone (Table 1). Although Sn, W, Mo, As, Sb, and $\mathrm{Bi}$ are known to be compatible in minerals like titanite, ilmenite, and magnetite (Candela and Bouton, 1990; Tacker and Candela, 1987), or in a fluid phase, all metals are either enriched in the melt inclusions, that is the residual melt, or are equal to the concentration of the whole rock (e.g., base metals $\mathrm{Pb}, \mathrm{Zn}$ ). This indicates a generally incompatible behavior of the metals during crystal fractionation at Timbarra.

In order to infer the evolution of those met- 


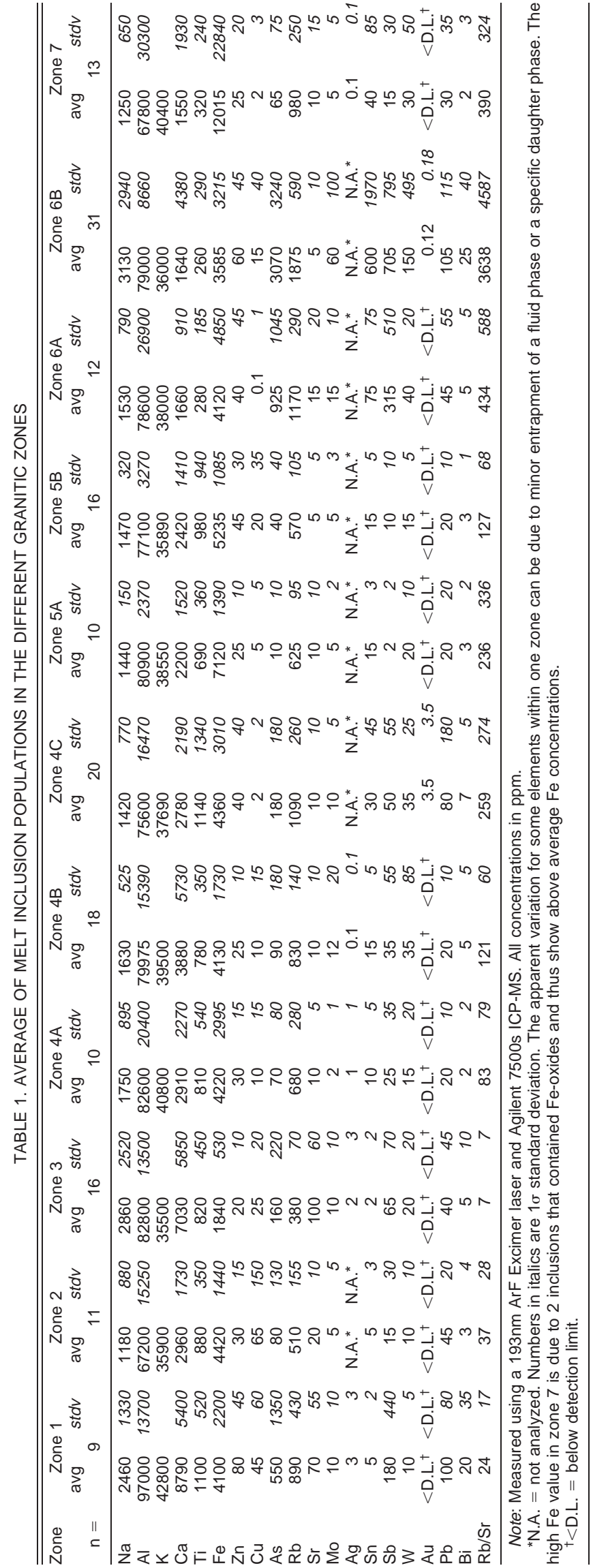

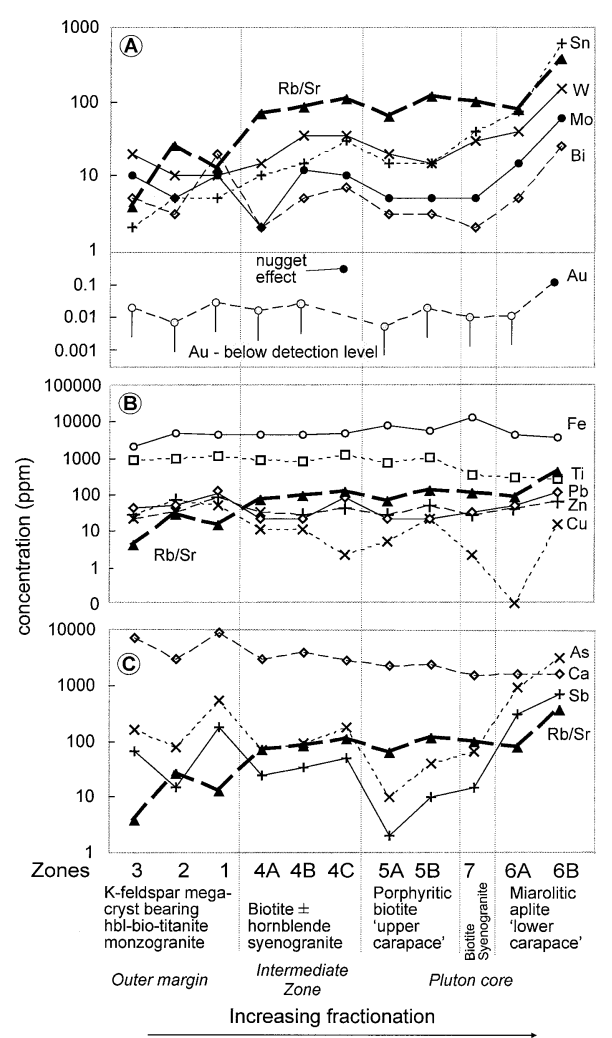

Figure 4. Metal behavior during increasing fractionation. Increasing $\mathrm{Rb} / \mathrm{Sr}$ indicates increasing fractionation and is shown as reference in all plots. A: Incompatible element behavior is reflected by increasing metal concentrations in residual melt. Gold is below detection limits (open symbols represent lowest detection limit of population of melt inclusions) for most zones in granite, except most fractionated (6B) and where large opaques are present in melt inclusions (nugget effect; e.g., zone 4C). B: Compatible trends are characterized by lower metal concentrations with increasing fractionation due to partitioning of metals into crystallizing phases such as titanite, ilmenite, magnetite, molybdenite, and tellurides. $\mathrm{C}$ : $\mathrm{Ca}$ shows generally compatible behavior, whereas As and Sb show incompatible characteristics in later stages. We speculate that coexisting fluid phase and/or onset of porphyritic crystallization may have temporarily depleted melt in As and $\mathrm{Sb}$ in zone $5 \mathrm{~A}$.

als and their enrichment factors in the magma, we compared the melt inclusion results from the least (zone 3 ) with the most fractionated zone (6B). The whole-rock metal content of zone 3 is very close to average crustal abundances for most of the metals. This implies that all the metal enrichment happened during fractionation and no pre-enriched melt existed. $\mathrm{Mo}, \mathrm{W}, \mathrm{Bi}, \mathrm{As}$, and $\mathrm{Sb}$ become more enriched $(5-20 \times)$ during fractionation compared to the base metals $\mathrm{Zn}, \mathrm{Pb}$, and $\mathrm{Cu}(1-3 \times)$. Gold shows a slightly higher enrichment factor (40 $\times$ ) calculated by assuming an average crustal concentration of $\mathrm{Au}$ of $0.003 \mathrm{ppm}$ for the least fractionated stage. Note that gold was not detected in the least fractionated stage using LA- 
ICP-MS. Tin shows the highest enrichment during fractionation $(300 \times)$.

We suggest that key factors of enriching the metals in the melt phase were the low content $(<1 \%)$ of accessory phases and the absence of early crystallizing sulfide phases, which could sequester chalcophile and siderophile elements (Candela, 1992; Cygan and Candela, 1995; Halter et al., 2002; Jugo et al., 1999; Keith et al., 1997; Lynton et al., 1993; Stimac and Hickmott, 1994; Tacker and Candela, 1987). The decreasing concentrations of Fe, $\mathrm{Ca}$, and $\mathrm{Ti}$ in the whole rock with increasing fractionation limited the occurrence of titanite to the earlier phases (zones 1-3). Minor Feoxides exist in all zones (melt inclusions with Fe-oxides from zones 6 and 7), but their modal abundance is low and they did not significantly influence the $\mathrm{Au}$ content and overall metal budget of the magma (Simon et al., 2003). Additional factors, such as (1) volatiles in the melt, (2) the lack of exsolution of an early Cl-bearing aqueous fluid, as well as (3) an increase in the degree of crystallization to $>99 \%$ during fractionation, appear to control the fractionation behavior of $\mathrm{Sn}, \mathrm{W}, \mathrm{Mo}, \mathrm{Bi}$, $\mathrm{As}, \mathrm{Sb}$, and $\mathrm{Au}$. In contrast, the fairly constant pressure regime and buffered redox conditions between hematite-magnetite and nickel-nickel oxide from $\sim 850{ }^{\circ} \mathrm{C}$ to $550{ }^{\circ} \mathrm{C}$ (Mustard, $2001,2004)$ result in an insignificant effect on the Sn solubility in the melt (Taylor and Wall, 1992; Thomas et al., 2000); incidentally, the metal that is most enriched in the residual melt at Timbarra and other granitic systems.

The volatiles fluorine (inferred from fluorite in the magmatic-hydrothermal transition stage 6B) and boron (boric acid detected by Raman spectroscopy) decreased the polymerization in the peraluminous melt. This increased the solubility of, e.g., W, Sn (London, 1995), and $\mathrm{H}_{2} \mathrm{O}$. Consequently, the crystallization temperature of the melt decreased and thus extensive crystal fractionation and metal enrichment were prolonged. Fluorine suppresses the exsolution of Cl-rich fluids, and delays $\mathrm{Cl}$ bearing fluid exsolution (Holtz et al., 1993; Thomas et al., 2000). Similarly, the enrichment of nonvolatile (e.g., Mo, W, Sn, Bi) and volatile elements (B, As, $\mathrm{Sb}$ ) that normally would show opposite partitioning in a meltfluid system implies the absence of early Clrich fluids (London, 1995). We found evidence for $\mathrm{CO}_{2}$-rich fluid exsolution (coexisting melt and $\mathrm{CO}_{2}$-rich fluid inclusions) during the early stages of fractionation (Lowenstern, 2001), but these fluids mitigate metal partitioning since effective partitioning and transport of most metals (i.e., $\mathrm{Sn}, \mathrm{Cu}, \mathrm{Pb}$, $\mathrm{Zn)}$ require Cl-rich fluids (Heinrich, 1990; Lehmann, 1990). Similarly, the small partitioning coefficients for $\mathrm{W}$, Mo, and $\mathrm{Sn}$ between fluid and melt (Keppler and Wyllie, 1991) and the low Cl-bearing fluid/melt ratios during the early magmatic stages preclude ef- fective metal removal by a fluid, resulting in a metal and volatile-rich silica residue. It was only at the late magmatic-hydrothermal transition stage and a high degree of crystallization that the presence of larger amounts of fluid was apparent. The metal-rich hybrid melt-fluid phase rose and accumulated in the apical part of the Stanthorpe intrusion. There the fluid was not spatially separated from the melt because the fluid pressure was not sufficient to overcome the lithostatic pressure of the carapace (zone 5), resulting in the disseminated $\mathrm{Au}$ mineralization style at Timbarra (zones 6 and 7). Magmatic mineralization occurred by cooling of the metal-rich melt and subsequent molybdenite saturation, followed by gold but not cassiterite due to its high solubility.

\section{CONCLUSIONS}

We propose that the very consistent enrichment factors for $\mathrm{Mo}, \mathrm{W}, \mathrm{Bi}, \mathrm{As}, \mathrm{Sb}$, and $\mathrm{Au}$, and base metals $\mathrm{Cu}, \mathrm{Pb}$, and $\mathrm{Zn}$ are due to a common process such as crystal fractionation and metal incompatible behavior, respectively. The much higher enrichment of Sn is possibly related to its completely incompatible behavior and its high solubility compared to some of the other metals that precipitated in the hydrothermal stage (e.g., molybdenite; Fig. 3). The similar enrichment factors for $\mathrm{Au}$ and, e.g., Mo, W, and Bi from average crustal values indicate that no gold-enriched melt is required.

Fractionation processes alone can account for the enrichment of metals to economic levels as long as they are not sequestered from the melt phase by either fluids or minerals. This may be a stringent case, but likely for highly fractionated, deep-seated $(5-10 \mathrm{~km})$ systems with Cl-poor fluids and low sulfide content $(\leq 1 \%)$ such as intrusion-related gold systems.

\section{ACKNOWLEDGMENTS}

We thank C. Allen and J.M.G. Shelley for technical support with the LA-ICP-MS and W. Halter, S. Eggins, T. Blenkinsop, and T. Baker for reviews of an earlier version of the manuscript. We also thank J. Lowenstern, R. Thomas, and C.A. Heinrich for constructive reviews.

\section{REFERENCES CITED}

Audétat, A., Günther, D., and Heinrich, C.A., 1998, Formation of a magmatic-hydrothermal ore deposit: Insights with LA-ICP-MS analysis of fluid inclusions: Science, v. 279, p. 2091-2094.

Bakke, A.A., 1995, The Fort Knox "porphyry" style gold deposit-Structurally controlled stockwork and shear quartz vein, sulphide-poor mineralisation hosted by a Late Cretaceous pluton, east-central Alaska: Canadian Institute of Mining and Metallurgy Transactions, v. 46, p. $795-803$.

Candela, P.A., 1992, Controls on ore metal ratios in graniterelated ore systems: An experimental and computational approach: Royal Society of Edinburgh Transactions, Earth Sciences, v. 83, p. 317-326.

Candela, P.A., 1997, A review of shallow, ore-related granites: Textures, volatiles, and ore metals: Journal of Petrology, v. 38 , p. $1619-1633$

Candela, P.A., and Bouton, S.L., 1990, The influence of oxygen fugacity on tungsten and molybdenum partitioning between silicate melts and ilmenite: Economic Geology, v. 85 , p. $633-640$

Cygan, G.L., and Candela, P.A., 1995, Preliminary study of gold partitioning among pyrrhotite, pyrite, magnetite, and chalcopyrite in gold-saturated chloride solutions at 600 to $700{ }^{\circ} \mathrm{C}, 140 \mathrm{MPa}$ (1400bars), in Thompson, J.F.H., ed., Magmas, fluids, and ore deposits: Mineralogical Association of Canada Short Course Series, p. 129-137.

Halter, W.E., Pettke, T., and Heinrich, C.A., 2002, The origin of $\mathrm{Cu} / \mathrm{Au}$ ratios in porphyry-type ore deposits: Science, v. 296 , p. $1844-1846$.

Hedenquist, J.W., and Lowenstern, J.B., 1994, The role of magmas in the formation of hydrothermal ore deposits: Nature, v. 370, p. 519-527.

Heinrich, C., 1990, The chemistry of hydrothermal tin (-tungsten) ore deposition: Economic Geology, v. 85 p. 457-481.

Holtz, F., Dingwell, D.B., and Behrens, H., 1993, Effect of F, $\mathrm{B}_{2} \mathrm{O}_{3}$ and $\mathrm{P}_{2} \mathrm{O}_{5}$ on the solubility of water in haplogranite melts compared to natural silicate melts: Contributions to Mineralogy and Petrology, v. 113, p. 492-501.

Jugo, P.J., Candela, P.A., and Piccoli, P.M., 1999, Magmatic sulfides and $\mathrm{Au}: \mathrm{Cu}$ ratios in porphyry deposits: An experimental study of copper and gold partitioning at $850^{\circ} \mathrm{C}$, $100 \mathrm{MPa}$ in a haplogranitic melt-pyrrhotite-intermediate solid solution-gold metal assemblage, at gas saturation: Lithos, v. 46 , p. $573-589$

Keith, J.D., Whitney, J.A., Hattori, K., Ballantyne, G.H, Christiansen, E.H., Barr, D.L., Cannan, T.M., and Hook, C.J., 1997, The role of magmatic sulfides and mafic alkaline magmas in the Bingham and Tintic mining district, Utah: Journal of Petrology, v. 28, p. 1679-1690.

Keppler, H., and Wyllie, P.J., 1991, Partitioning of Cu, Sn, Mo, $\mathrm{W}, \mathrm{U}$, and Th between melt and aqueous fluid in the system haplogranite- $\mathrm{H}_{2} \mathrm{O}-\mathrm{HCl}$ and haplogranite- $\mathrm{H}_{2} \mathrm{O}-\mathrm{HF}$ : Contributions to Mineralogy and Petrology, v. 109, p. $139-150$.

Lang, J.R., and Baker, T., 2001, Intrusion-related gold systems: The present level of understanding: Mineralium Deposita, v. 36 , p. $477-489$.

Lang, J.R., and Titley, S.R., 1998, Isotopic and geochemical characteristics of Laramide magmatic systems in Arizona and implications for the genesis of porphyry copper deposits: Economic Geology, v. 93, p. 138-170.

Lehmann, B., 1990, Metallogeny of tin, in Bhattacharji, S., et al., eds., Metallogeny of tin: Lecture Notes in Earth Sciences: Berlin, Springer Verlag, $211 \mathrm{p}$.

London, D., 1995, Geochemical features of peraluminous granites, pegmatites, and rhyolites as source of lithophile metal deposits, in Thompson, J.F.H., ed., Magmas, fluids, and ore deposits: Mineralogical Association of Canada Short Course Series, v. 23, p. 175-202.

Lowenstern, J.B., 2001, Carbon dioxide in magmas and implications for hydrothermal systems: Mineralium Deposita, v. 36, p. 490-502.

Lynton, S.J., Candela, P.A., and Piccoli, P.M., 1993, An experimental study of the partitioning of copper between pyrrhotite and a high silica rhyolitic melt: Economic Geology, v. 88, p. 901-915.

Mustard, R., 2001, Granite-hosted gold mineralization at Timbarra, northern New South Wales, Australia: Mineralium Deposita, v. 36 , p. $542-562$.

Mustard, R., 2004, Textural, mineralogical and geochemical variation in the zoned Timbarra Tablelands pluton, New South Wales: Australian Journal of Earth Sciences, v. 51 , p. $387-407$.

Simon, A.C., Pettke, T., Candela, P.A., Piccoli, P.M., and Heinrich, C.A., 2003, Experimental determination of Au solubility in rhyolite melt and magnetite: Constraints on magmatic Au budgets: American Mineralogist, v. 88 p. $1644-1651$.

Stimac, J., and Hickmott, D., 1994, Trace-element partition coefficients for ilmenite, orthopyroxene and pyrrhotite in rhyolite determined by micro-PIXE analysis: Chemical Geology, v. 117, p. 313-330.

Tacker, R.C., and Candela, P.A., 1987, Partitioning of molybdenum between magnetite and melt; a preliminary experimental study of partitioning of ore metals between silicic magmas and crystalline phases: Economic Geology, v. 82 , p. $1827-1838$

Taylor, J.R., and Wall, V.J., 1992, The behavior of tin in granitoid magmas: Economic Geology, v. 87, p. 403-420.

Thomas, R., and Webster, J.D., 2000, Strong tin enrichment in a pegmatite-forming melt: Mineralium Deposita, v. 35 , p. $570-582$.

Thompson, J.F.H., Sillitoe, R.H., Baker, T., Lang, J.R., and Mortensen, J.K., 1999, Intrusion-related gold deposits associated with tungsten-tin provinces: Mineralium Deposita, v. 34 , p. $323-334$.

Ulrich, T., Günther, D., and Heinrich, C.A., 1999, Gold concentrations of magmatic brines and the metal budget of porphyry copper deposits: Nature, v. 399, p. 676-679.

Manuscript received 5 August 2005

Revised manuscript received 6 October 2005

Manuscript accepted 11 October 2005

Printed in USA 